\title{
Title:
}

\section{Dubin-Johnson syndrome as a laparoscopic finding}

\section{Authors:}

Alba Cebrián García, David Ruiz-Clavijo García, Alba Larrea Ramírez, Beñat Arín Palacios

DOI: $10.17235 /$ reed.2021.7866/2021

Link: PubMed (Epub ahead of print)

Please cite this article as:

Cebrián García Alba, Ruiz-Clavijo García David, Larrea Ramírez Alba, Arín Palacios Beñat. Dubin-Johnson syndrome as a laparoscopic finding. Rev Esp Enferm Dig 2021. doi: 10.17235/reed.2021.7866/2021.

This is a PDF file of an unedited manuscript that has been accepted for publication. As a service to our customers we are providing this early version of the manuscript. The manuscript will undergo copyediting, typesetting, and review of the resulting proof before it is published in its final form. Please note that during the production process errors may be discovered which could affect the content, and all legal disclaimers that apply to the journal pertain. 


\section{Dubin-Johnson syndrome as a laparoscopic finding}

Alba Cebrián García; David Ruiz-Clavijo García; Alba Larrea Ramírez³; Beñat Arín Palacios ${ }^{4}$

1. Unidad de Aparato Digestivo, Hospital Reina Sofía. Tudela, Navarra.

2. Servicio de Aparato Digestivo, Complejo Hospitalario de Navarra. Pamplona, Navarra.

3. Servicio de Anatomía Patológica, Complejo Hospitalario de Navarra. Pamplona, Navarra.

4. Servicio de Cirugía General. Hospital García Orcoyen. Estella, Navarra.

Correspondence: Alba Cebrián García. E-mail: albacebriangarcia@gmail.com

Key words: Dubin-Johnson syndrome, conjugated hyperbilirubinemia.

\section{CLINICAL CASE}

We present the case of a 35-year-old woman with a history of polycystic ovary syndrome, treated with oral contraceptives who was under study for 9 months evolution pain in the right iliac fossa, associated with hyporexia and mild hyperbilirubinemia with a predominance of the conjugated fraction (total Bi $3.7 \mathrm{mg} / \mathrm{dL}$, conjugated Bi $2.9 \mathrm{mg} / \mathrm{dL}$ ). An abdominal computed tomography (CT) was performed showing homogeneous hepatosplenomegaly and adenopathies in both iliac chains, the biggest in the right external iliac chain of 1,6 x 3,6 cm. As a result, a laparoscopy was performed to biopsy the lymphadenopathies in the course of which it was observed a black liver surface (Fig. 1), which was biopsied. The anatomopathological study of the liver described brown pigment granules in centrilobular hepatocytes that stain irregularly with PAS, which were identified as lipomelanin, compatible with DubinJohnson Syndrome (DJS) (Fig. 2). The anatomopathological result of pelvic 
lymphadenopathies was non-necrotizing granulomatous lymphadenitis, whose study is being completed.

\section{DISCUSSION}

DJS is a benign autosomal recessive inherited disorder characterized by hyperbilirubinemia with a predominance of the conjugated fraction and an alteration in the metabolism of coproporphyrins (more urinary excretion of coproporphyrin 1 than III) ${ }^{1}$. It is caused by a mutation in a bilirubin transporter, called MRP2, which takes the conjugated bilirubin and introduces it into the bile duct ${ }^{2}$. Its prevalence has been estimated at less than 1 case per 100.000 inhabitants, being more prevalent in Iranian Jews ${ }^{3}$. The most common symptom is jaundice. The liver is characteristically black due to intracellular deposit of a melanin-like pigment. The main differential diagnosis is with Rotor Syndrome in which high urinary concentrations of both total coproporphyrin and coproporphyrin I are observed and the blackish pigment of the liver does not occur (Table 1). Due to its benign prognosis, no specific treatment is required.

\section{REFERENCES}

1. Memon N, Weinberger BI, Hegyi $\mathrm{T}$ et al. Inherited disorders of bilirubin clearance. Pediatr Res. 2016 Mar;79(3):378-86.

2. Keitel V, Nies A, Brom $M$ et al. A common Dubin-Johnson syndrome mutation impairs protein maturation and transport activity of MRP2 (ABCC2). Am J Physiol (Gastrointest Liver Physiol) 2003; 284:165-174.

3. Dubin IN. Chronic idiopathic jaundice; a review of fifty cases. Am J Med. 1958 Feb;24(2):268-92. 


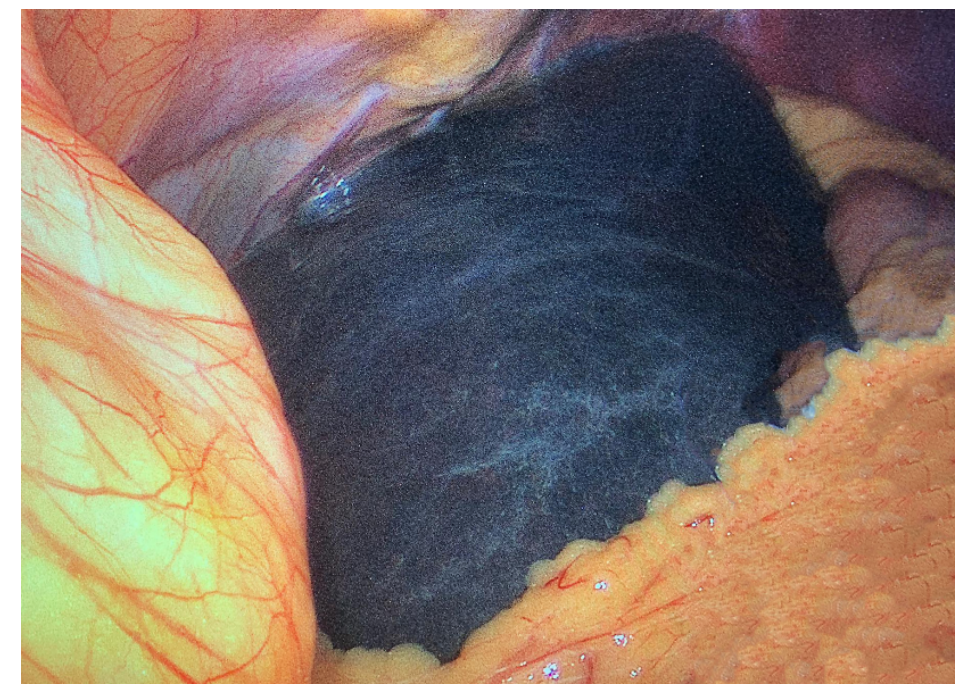

Figure 1. Laparoscopic image of the liver showing a regular surface and a blackish color of the parenchyma.

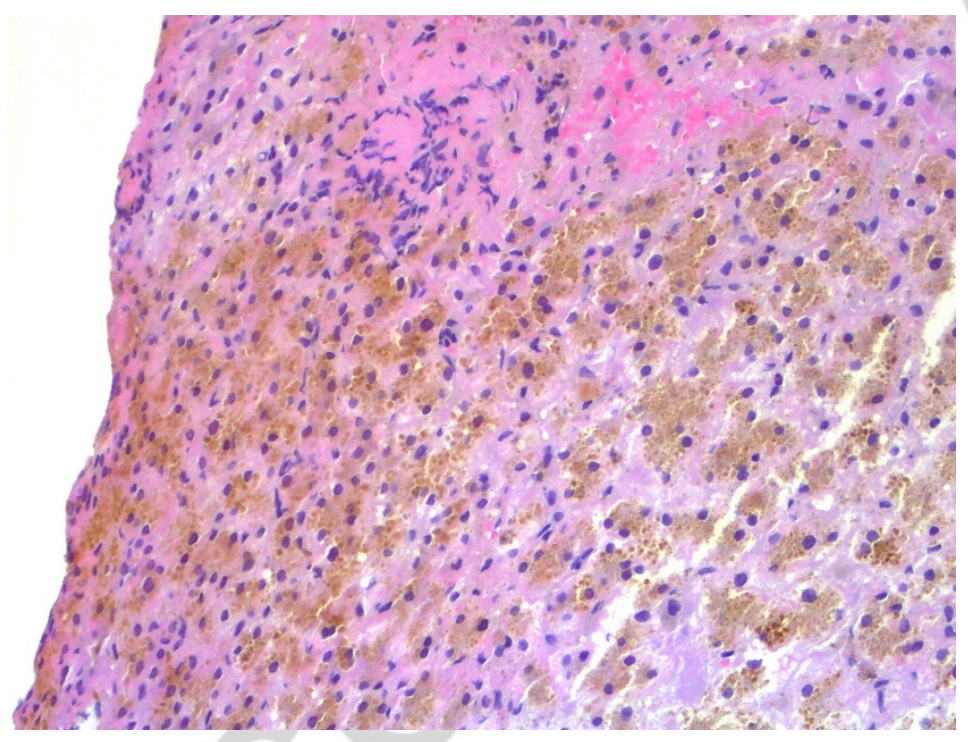

Figure 2. Liver biopsy: presence of brown intracytoplasmic pigment. 


\begin{tabular}{|l|c|c|}
\hline & Dubin-Johnson & \multicolumn{1}{c|}{ Rotor } \\
\hline Incidence & Rare & Exceptional \\
\hline Inheritance & \multicolumn{2}{|c|}{ Autosomal recessive } \\
\hline Bilirubin & $2-5 \mathrm{mg} / \mathrm{dl}(60 \%$ conjugated $)$ \\
\hline Symptoms & \multicolumn{1}{|c|}{ Asymptomatic jaundice } \\
\hline Liver pathology & $\begin{array}{c}\text { Presence of dark pigments in } \\
\text { centrilobular areas }\end{array}$ & Normal \\
\hline $\begin{array}{l}\text { Urinary excretion of } \\
\text { coproporphyrin }\end{array}$ & $\begin{array}{c}\text { Total normal } \\
\text { High isomer I }\end{array}$ & $\begin{array}{c}\text { Total elevated } \\
\text { High isomer I }\end{array}$ \\
\hline Prognosis & Benign & Benign \\
\hline
\end{tabular}

Table 1. Differences between Dubin-Johnson Syndrome and Rotor Syndrome 